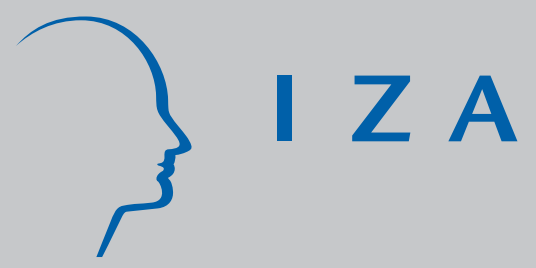

IZA DP No. 3776

Workforce Development as an Antipoverty Strategy: What Do We Know? What Should We Do?

Harry J. Holzer

October 2008 


\title{
Workforce Development as an Antipoverty Strategy: What Do We Know? What Should We Do?
}

\author{
Harry J. Holzer \\ Georgetown University, \\ Urban Institute and IZA
}

Discussion Paper No. 3776

October 2008

\author{
IZA \\ P.O. Box 7240 \\ 53072 Bonn \\ Germany \\ Phone: +49-228-3894-0 \\ Fax: +49-228-3894-180 \\ E-mail: iza@iza.org
}

\begin{abstract}
Any opinions expressed here are those of the author(s) and not those of IZA. Research published in this series may include views on policy, but the institute itself takes no institutional policy positions.

The Institute for the Study of Labor (IZA) in Bonn is a local and virtual international research center and a place of communication between science, politics and business. IZA is an independent nonprofit organization supported by Deutsche Post World Net. The center is associated with the University of Bonn and offers a stimulating research environment through its international network, workshops and conferences, data service, project support, research visits and doctoral program. IZA engages in (i) original and internationally competitive research in all fields of labor economics, (ii) development of policy concepts, and (iii) dissemination of research results and concepts to the interested public.
\end{abstract}

IZA Discussion Papers often represent preliminary work and are circulated to encourage discussion. Citation of such a paper should account for its provisional character. A revised version may be available directly from the author. 
IZA Discussion Paper No. 3776

October 2008

\section{ABSTRACT \\ Workforce Development as an Antipoverty Strategy:
What Do We Know? What Should We Do?}

In this paper I note the basic paradox of workforce development policy: that, in an era in which skills are more important than ever as determinants of labor market earnings, we spend fewer and fewer public (federal) dollars on workforce development over time. I present trends in funding and how the major federal programs at the Department of Labor and other agencies have evolved over time, noting the dramatic declines in funding (with the exception of Pell grants). I then review what we know about the cost-effectiveness of programs for adults and youth from the evaluation literature. I consider some other possible reasons for funding declines, such as the notion that other approaches (like supplementing the low earnings of workers with tax credits or early childhood programs) are more effective and address more serious problems. I review some newer developments in workforce policy, mostly at the state and local levels, and then conclude with some policy recommendations.

JEL Classification: J24

Keywords: $\quad$ workforce development, poverty

Corresponding author:

Harry J. Holzer

Georgetown Public Policy Institute

3600 N St. NW, Ste. 202

Washington DC 20007

USA

E-mail: hjh4@georgetown.edu

\footnotetext{
* I am grateful to Maria Cancian, Sheldon Danziger, Carolyn Heinrich, Karl Scholz and other conference participants for helpful comments. Igor Kheyfets provided excellent research assistance.
} 


\section{The Paradox of Workforce Development for the Poor}

Over the past few decades, the gaps in earnings between more- and less-educated American workers have risen. The numbers of adult workers in low-wage jobs has risen - partly because of the growing supply of these workers, associated with welfare reform and immigration (among other forces), and partly because of growing demand for these workers in low-paying jobs (Autor et al. 2006). And, at least among less-educated and minority men, the numbers with criminal records and other characteristics that make them "hard to employ" has risen dramatically as well.

A consensus has developed among economists and policy analysts on the increased importance that workforce skills play in explaining the labor market problems of the disadvantaged. The lack of skills and educational credentials among disadvantaged groups, like racial and ethnic minorities and the poor, contributes to their low employment and earnings and inhibits their ability to advance in the labor market. As a result, many policymakers and researchers have suggested increased public investments in improving early education opportunities, reforming school practices in the K-12 years, and improving access to higher education (Heckman 2008; Jacob and Ludwig, this volume).

In contrast, there is no such consensus about the ability of "workforce development” (or job training programs) to raise employment and earnings for disadvantaged youth and adults. Federal funding of these efforts has greatly diminished over time both in real terms and especially relative to the size of the economy, even though the economic rewards to skills have grown. Why has support for workforce development policies fallen so far as an antipoverty strategy? What are the most recent developments in the field, and what is the state of knowledge about their success? Is a resurgence of interest in workforce development for the poor merited? 
And, for low-wage workers for whom workforce development is unlikely to be a successful option, what other policies might work?

In this chapter, I address these questions. I first review trends in federal funding and the evolution of major workforce development programs and evaluation evidence about their costeffectiveness. I then describe promising new approaches. I conclude with some thoughts on what a workforce development agenda might include, and what is needed for such an agenda to succeed.

\section{Trends in Federal Funding and the Evolution of Workforce Development Programs}

\section{A. Training Programs at the Department of Labor}

Since the early 1960s, and especially since the declaration of the "War on Poverty" in 1964, the U.S. Department of Labor has funded employment and training services for the disadvantaged, along with other workers. Over the years, these efforts have evolved through several major pieces of legislation: 1) the Manpower Development Training Act (MDTA), 196273; 2) the Comprehensive Employment and Training Act (CETA), 1974-84; 3) the Job Training Partnership Act (JTPA), 1984-99; and 4) the Workforce Investment Act (WIA), 1999-present. ${ }^{1}$ These legislative developments reflect changes in priorities and perspectives on employment and training for the disadvantaged held by Congress various presidential administrations. For instance, MDTA provided direct federal grants to local service providers. In 1965, it began to fund the Job Corps, which provides a year of education and training to disadvantaged youth at residential centers around the country.

With CETA, the federal government began to devolve responsibility for some employment and training to state and local advisory committees. Funding for employment and 
training increased dramatically in the late-1970s, as employment levels among low-income and especially minority adults and youth were deteriorating. "Public service employment” was provided to 750,000 individuals in 1978 (Ellwood and Welty 2000), about 10 percent of all unemployed individuals, under the view that they would have difficulty obtaining employment on their own in the private sector.

With the passage of JTPA in 1984, the Reagan Administration eliminated public service employment, which it regarded as a wasteful substitution for employment which otherwise would exist in the private sector. ${ }^{2}$ Funds were dispersed by “private industry councils” (or PICs) that were expected to reflect local demand for labor. The notion of a “demand-driven” system was further implemented with WIA in 1999, in which local “workforce investment boards” (or WIBs) were to reflect the needs of local businesses, who now controlled the majority of seats on any board. Any remaining vestiges of public employment that were still available (in the summer youth programs, for example) were also eliminated.

Title I of WIA is now the primary vehicle for federal funding of job training and employment services. It focuses on three groups: adults, youth (mostly in-school) and dislocated workers. The latter group includes adults who have permanently and involuntarily lost a job due to plant closing or downsizing, regardless of skill level or wage. Title I still funds the Job Corps for disadvantaged youth, and smaller programs for Native Americans, ex-offenders, veterans, and migrant and seasonal farm workers, among others. ${ }^{3}$

Worker training under WIA - which might be defined as any kind of education that directly prepares workers for specific occupations or jobs - potentially includes many types of activities. These can occur in the classroom or on the job, both formally and informally, for workers either currently employed or not employed. ${ }^{4}$ Workers now have greater control over 
how to spend their training funds, particularly when they receive vouchers known as Individual Training Accounts (or ITAs). WIA created the "One-Stop” offices at which workers gain access to all services funded by the Labor Department, including Unemployment Insurance and use of the Public Employment Service, the primary provider of public "labor exchange" services., where unemployed workers can find out about available jobs by consulting job postings submitted to the government by private employers (O’Leary et al. 2004).

WIA reflects a belief in empowering local employers and workers, and in providing services to a broader population that can be quickly matched to existing jobs. Importantly, adult services are no longer targeted only to the disadvantaged. This was partly done to remove any stigma that might have been associated with publicly provided employment and training services from the perspective of employers.

There are three categories of employment services for adults: core, intensive, and training. Core services involve self-directed use of the Employment Service and other local employment listings as well as staff-assisted job search. Intensive services consist of assessments of job skills and counseling. Each service must be accessed by individuals before they can receive training, and many are diverted into the workforce without receiving any training. Thus, WIA reflects the "work-first” philosophy (embodied in "welfare reform”) of getting as many people as quickly as possible into private sector jobs.

The goal of making services more universally available has been achieved, as lowincome individuals now make up only about 20 percent of non-dislocated adult registrants and just over half of those receiving training. In contrast, non-dislocated adults served under CETA and JTPA were primarily disadvantaged until the late 1990s. Dislocated workers are less likely to have been low-income before their displacement, and their share of training recipients has 
grown over time. The numbers and shares of all WIA participants receiving any training has declined as well, as has the average duration of such training; core and intensive services for the non-disadvantaged who take jobs without any new training now consuming more resources than prior to WIA (Frank and Minoff 2005). ${ }^{5}$

What has happened to overall federal funding levels for employment and training programs at the Department of Labor? Total expenditures under Title I of WIA (Fiscal Year 2008) were roughly $\$ 860 \mathrm{M}, \$ 1.2 \mathrm{~B}$, and $\$ 924 \mathrm{M}$ for adult, displaced and youth services respectively, plus about $\$ 1.7 \mathrm{~B}$ for the Job Corps. If funding for several smaller programs is included, total federal spending is about \$5.5 B. To compare current spending with that in earlier years, Figure 1 plots annual expenditures on employment and job training from MDTA in 1963 through WIA in 2003 in constant dollars. After peaking in real terms in 1979 at about \$17B, funding declined until 1985, and has either remained flat or declined more since then. By 2003, inflation-adjusted funding had fallen by about 65 percent from its 1979 peak; by 2008, by nearly 70 percent. However, because the real economy has more than doubled in size since 1979, this funding has fallen by about 87 percent in relative terms - from roughly .30 percent to .04 percent of Gross Domestic Product (GDP). Since 1985, funding in relative terms has declined from .08 to .04 percent of GDP. Because WIA now funds a broader range of services for a broader set of participants than it did 30 years ago, the decline in spending on the disadvantaged, especially for direct employment or training, has been even greater.

\section{B. Other Workforce Development Programs}

This picture of declining training over time would be inaccurate if funds for training in programs outside the Labor Department had increased sufficiently. In fact, a criticism of government programs for low-income individuals is the extent to which they appear in multiple 
agencies s in the federal budget, with inefficiencies associated with overlapping clientele and jurisdictions.

A recent government report shows spending on about 40 federal employment and training programs (U. S. Government Accountability Office 2003). ${ }^{6}$ These programs overall accounted for over \$34B in spending; but actual expenditures on employment and training within these programs accounted for a much smaller amount - roughly \$14B. These expenditures amount to just over $0.1 \%$ of GDP - a smaller fraction than is spent on training or workforce development virtually anywhere else in the industrial world (Heckman et al. 1999; O’Leary et al. 2004).

As mentioned, much of this spending does not target the disadvantaged. About threequarters of all training expenditures are accounted for by WIA Title I services for adults, youth, displaced workers and the Job Corps, plus funds expended under State Vocational Rehabilitation Services and Temporary Assistance for Needy Families (TANF). Vocational services target the disabled, and not necessarily disadvantaged; TANF training funds constitute a very small share of total TANF expenditures on welfare recipients or other needy families. Spence and Kiel (2003) find that expenditures on education and training account for only about 2 percent of federal TANF expenditures, a major reductions relative to what was spent in the pre-TANF era on other employment programs for welfare recipients. This reflects the reorientation of welfare programs towards "work first" approaches, generally to the exclusion of workforce training. Even if we add estimates of training expenditures funded by various block grants from HHS to the states, like the Social Services Block Grant and Community Services Block Grant (SSBG and CSBG respectively), this picture does not change fundamentally. ${ }^{7}$

The GAO report does not include expenditures by the Department of Education on vocational training (funded through the Perkins Act) or on college scholarships in the form of 
Pell Grants (funded through the Higher Education Act). Perkins expenditures (of roughly \$1.2B annually) accrue mainly to high schools and 2-year technical colleges; thus, most funding goes to very young people. Funding for Perkins has been flat in nominal terms for many years and has declined in real terms.

Interest in Career and Technical Education (CTE, formerly known as "vocational education") or in "School-to-Career" programs that blend academic and occupational education with appropriate work experience for high school youth (both poor and non-poor) has also dwindled over time. Modest federal funding for The School-to-Work Opportunity Act, which provided about \$50M each year in seed money to local school districts to develop new "schoolto-work" programs with local employers between 1996 and 2001, has been eliminated.

Pell grants are the primary source of federal scholarship funds for college attendance among the poor - including those receiving occupational training at community colleges. ${ }^{8}$ Pell expenditures have risen in recent years from roughly \$6.6B in 1990-91 (or over \$9B in 2008 dollars) to \$14B in 2007-08. These finance higher education among low-income youth or adults. Nonetheless, the recent increases in Pell funding have fallen short of rising tuition costs and overall student needs. ${ }^{9}$ Eligibility for Pell grant use is limited to those taking classes at accredited community colleges at least half-time, thereby excluding other training providers and students taking classes less than half-time; at community colleges, many short-term or remedial classes taken by poor students are not covered by Pell funding. ${ }^{10}$

In short, expenditures outside of DOL on employment and training have increased in some cases and decreased in others, but they have not fully offset the dramatic declines that have occurred in the former, especially relative to the growing needs of the low-income populations. 


\section{Why Has Funding and Interest in Training Fallen?}

\section{A. Perceptions of Ineffectiveness: The Evaluation Literature}

A major reason for the decline over time in public spending on and interest in workforce development has been a widespread perception that the programs are not cost-effective at raising future earnings of participants. There is little doubt about the large private and social returns to education and training in our economy. But why might training for disadvantaged adults or youth, in publicly funded programs, be less effective?

One reason might be that the basic cognitive skills of disadvantaged adults are too weak for limited occupational training to effectively raise. Another might be that their motivation to participate in training is low, especially if the programs are time-consuming. This might be particularly true for working (especially single) parents who are already pressed for time, or for youth who are not yet ready to “settle down.” Or perhaps prospective employers are not impressed by any government-sponsored training, if their other educational and work experiences are weak.

Is the general perception of program ineffectiveness warranted by the evidence (Heckman et al. 1999; Lalonde 2003)? Below I briefly summarize the evaluation literature and draw implications for workforce development policy. The estimated impacts of training programs for disadvantaged workers on their later earnings in this literature vary considerably with demographic group, with more positive impacts generally observed for adult women than men and for adults than for out-of-school youth. The estimated impacts also vary with the following: 1) Whether program participation has been voluntary or mandatory; 2) Whether participants are "hard to employ," with more severe disabilities or barriers to work (such as criminal records, substance abuse or very poor skills); 3) The duration and/or intensity of the 
treatment; 4) The nature and content of the treatment - i.e., whether it focused primarily on classroom training, on-the-job training, work experience.; 5) The scale of the program considered, and whether or not it is a replication effort; 6) Whether the evaluation uses survey or administrative data.

\section{Programs for Disadvantaged Adults}

The evidence on training programs for disadvantaged adults can be summed up as: modest expenditures usually produce modest positive impacts. The evidence derives from the experimental National JTPA Study (NJS) of the early 1990s, as well as earlier nonexperimental studies of CETA and more recent ones of WIA. Evaluations of various welfare-to-work programs also lead to similar conclusions.

Estimates of impacts on annual earnings of adult men and women in the NJS within 30 months of random assignment are over \$800 (10\% and 16\% respectively for men and women) for those who actually enrolled in the training program (or about \$1150 in 2007 dollars), and somewhat smaller for all those who were assigned but did not participate (Bloom et al. 1997). ${ }^{11}$ Earnings gains were observed both for those engaged in classroom and on-the-job training. Although earnings gains were driven more by increases in employment rates than in hourly wages for enrollees, there is at least some modest evidence of both. ${ }^{12}$

These increases in annual earnings are modest and seem to fade somewhat over time (USGAO 1996). However, these magnitudes need to be compared to program costs. While the average cost of treatment was about \$2300, those in the control group also enrolled in other services. The net NJS costs per enrollee were about \$1000 for adult men and \$1300 for adult women for over 200 hours of net increase in training (or \$1580 and \$2050 in 2007 dollars), and the net costs per assignee were roughly \$650 and 850 (or \$1025 and \$1340 in 2007 dollars) 
respectively. ${ }^{13}$ Thus, the returns per net dollar spent in JTPA were quite impressive; even with the fading out of positive impacts, the program pays for itself over 5 years. For instance, the sum of earnings impacts per assignee, after adjusting for inflation and discounting at .05, are well over double the net costs of the program (USGAO, 1996). Heckman et al. (1999) also report net social gains of up to $\$ 1000$ or more (or over $\$ 1400$ in 2007 dollars) for the 5-year follow-up period for adult men and women each, even assuming annual discount rates up to $10 \%$ and various estimates of the "welfare cost" to the economy of each dollar of taxation. ${ }^{14}$ Such gains represent a near doubling of total benefits generated by the program, relative to its costs.

Recent training programs for poor adults have emphasized community college attendance paid for by Pell grants. The evidence suggests that these grants raise rates of college attendance among poor adults, though not necessarily for youth (Turner, 2007). Whether attending community college generates significant earnings gains for disadvantaged adults is less clear. Statistical (but not experimental) studies show significant returns for disadvantaged populations that attend community college for at least one year, especially when they gain a certificate or degree (Lerman, 2007).

Evaluations of other programs, including mandatory welfare-to-work programs or voluntary work experience programs for women, involve a variety of different treatments (with more or less training) and led to mixed results. For instance, the mandatory GAIN program in Riverside, CA provided job search assistance but relatively little training and generated fairly sizable increases in subsequent employment rates (Riccio et al. 1994). But Hotz et al. (2000) find significant long-term returns to training at the Los Angeles and Oakland GAIN sites. The Saturation Work Initiative Model (SWIM) and Community Work Experience Program (CWEP) in San Diego, which combined job search assistance and some work supports with limited 
training with mandatory work experience, also generated fairly large impacts per dollar spent (Lalonde 2003). ${ }^{15}$ However, other work experience programs which provided fewer supports and training services were less effective in generating lasting employment increases.

The National Evaluation of Welfare-to-Work Strategies (NEWWS), implemented in the mid-1990s, included both "human capital" and "labor market attachment" strategies for welfare recipients, where the latter were less expensive than the former (Hamilton et al. 2001). The NEWWS evaluation found that the training programs were less effective than the labor market attachment programs, though impacts from both tended to fade with time. However, the Portland, Oregon site generated large and lasting impacts, using a "mixed strategy" in which most participants faced pressure to seek work while case managers allowed access to job training at community college for those whom they thought would benefit. ${ }^{16}$ Participants were also encouraged to search for higher-paying jobs at the outset, rather than accepting the first job they found. Mixed strategies that combine employment services (like job placement assistance) with other supports, such as earnings supplements, have also shown positive impacts elsewhere. ${ }^{17}$ And some nonexperimental evidence suggested that the NEWWS sites that provided occupational training rather than general adult education generated somewhat larger impacts at the "human capital" sites (Bos et al. 2001).

Another effective treatment for harder-to-employ welfare recipients was the National Supported Work (NSW) demonstration. Participants were given 12-18 months of paid work experience plus additional supports. Lalonde (2003) reports sizable impacts for adult women which were cost-effective if they persist. ${ }^{18}$ In contrast, the estimated impacts for adult men with criminal records and disadvantaged youth were not significant. However, a reexamination of the results for adult men (Uggen 2000) suggested significant reductions in recidivism for men above 
age 27, consistent with other evidence on offenders aging out of crime. On the other hand, we have little rigorous evidence to date of programs that raise their earnings.

Other examples of programs for disadvantaged adults deserve mention. An experimental evaluation of the Center for Employment Training (CET) in San Jose in the late 1980s showed large positive impacts on earnings. ${ }^{19}$ This program represented a new approach to training, in which the services are closely aligned with the needs of local employers, with whom the training providers were in close touch (Melendez 1996). An effort to replicate that model in other sites in the 1990s generated weaker impacts (Miller 2005), partly because the control group members in high-fidelity sites (mostly in California) received unusually high amounts of community college training on their own.

Important questions remain about how to interpret these results. On the one hand, impact estimates from random experiments might be biased downwards by the tendency of control group members to get services or training on their own - which apparently was the case in the CET replication and with JTPA (Heckman et al. 1999). This raises an important question of exactly what the "counterfactual" should be when judging the impact of specific training program: should outcomes for individuals in these programs be compared to those with no training at all, or those who receive other forms of training already quite available (at least in some places)? On the other hand, positive impacts estimated for small programs might overstate the potential social benefits of replicating and expanding these efforts, especially if large-scale programs might cause other workers to be displaced by program participants.

Also, the NJS study refers to training efforts around 1990; since then, JTPA has been transformed into WIA, which provides different training services (often shorter-term) to a different set of individuals. Unfortunately, there has not been a randomized evaluation of WIA, 
though there is some positive nonexperimental evidence (Mueser et al. 2005). Indeed, WIA cannot be considered a "program," as it is simply a set of funding streams that are locally dispersed in many different ways. We have little knowledge of which efforts are relatively more or less cost-effective for the disadvantaged, and especially the hard-to-employ. Similar questions remain about how to interpret the results from welfare-to-work programs like Portland NEWWS and Riverside GAIN after the 1996 welfare reform dramatically changed welfare. And we know little about the effectiveness of other important kinds of services, such as Adult Basic Education (including English language instruction for immigrants). ${ }^{20}$ Nonetheless, I conclude that many modest programs for disadvantaged adults in the past have worked reasonably well, as have a few intensive efforts for the "harder to employ".

\section{Programs for Disadvantaged Youth}

If training programs for disadvantaged adults are at least modestly cost-effective, those for disadvantaged youth have been disappointing, but somewhat better than the conventional wisdom. For example, the short-term training provided by JTPA for disadvantaged youth was at best ineffective, and at worst counterproductive (Bloom et al., 1997). More intensive programs, like the Job Corps, have seemed more promising. The Job Corps provides year-long training to over 60,000 disadvantaged youth each year at over 100 residential centers nationwide; besides the education and training they receive, residence at the centers enables young people to escape their low-income family or neighborhood settings and likely more negative parental or peer influences that might counteract positive influences of training. ${ }^{21}$

The earliest experimental evaluations of the Job Corps showed positive impacts on youth wages and hours of work for up to 30 months after enrollment; there were also significant increased in the acquisition of GEDs and vocational certificates and reductions in crime and 
incarceration. Program costs per participant (roughly \$20,000 currently) were more than offset by social gains, since there was no early evidence that the positive impacts faded over time. However, a follow-up study (Schochet et al. 2003) finds that positive impacts of the Job Corps faded away by the fourth year after random assignment. For those aged 20-24 when in the program, positive impacts persist somewhat. But the notion that Job Corps represents an effective intervention for out-of-school, disadvantaged youth in the long run has certainly been called into question.

Still, it is misleading and premature to infer that nothing works for disadvantaged youth, in part because recent training efforts for disadvantaged in-school youth seem promising. For example, Career Academies represent a new approach to career and technical education for young people in high school. Each academy is a "school within a school" that provides training and work experience within a particular sector of the economy. Kemple (2008) shows that Career Academies raise earnings by $1 \%$, relative to the control group, and the impacts persist for at least eight years after high school graduation. These gains are larger for disadvantaged young men than for other young men, and stronger for young men than women - a rare finding. Positive impacts were observed on wages as well as employment rates. ${ }^{22}$ Despite concerns over whether career education "tracks” minority or low-income youth into non-college trajectories, the experimental groups completed post-secondary education at the same rate as those in the control groups, and suffered no loss (or gain) in academic achievement. Nonexperimental evaluations of other school-to-work programs (Lerman 2007) indicate similar positive impacts on earnings and on high school graduation.

Attendance, retention and achievement of at-risk youth at community or 4-year colleges can also be enhanced. While Pell grants alone may not currently accomplish this goal for youth 
(Turner, 2007), the package of additional financial supports and services in the Opening Doors project appear to be more successful in this regard (Richburg-Hayes 2008). A variety of proposals to simplify federal grants and student loan applicants might also make Pell grants and other forms of aid more effective at raising college attendance for youth than they currently appear to be (Dynarski and Scott-Clayton 2007).

Even for out-of-school disadvantaged youth, it is too soon to conclude that nothing works. A short-term experimental evaluation of the Youth Service and Conservation Corps (Jastrzab 1997) showed strong positive impacts on a range of youth employment and behavioral outcomes, at least during the duration of the program; a longer term evaluation of more sites is currently underway. Outcomes for Youth Build also suggest positive impacts on educational attainment and negative effects on recidivism, though no rigorous evaluations have yet been performed (Cohen and Piquero 2008). And other models, like the "military" approach of the National Guard's ChalleNGe program, are currently being evaluated.

While employment programs for youth (either summer or year-round) have largely been eliminated from WIA, their short-term impacts might be more positive than have been appreciated. The Youth Incentive Employment Pilot Project (YIEPP) in the late 1970s, which guaranteed a publicly-funded job to participating youth, had large positive impacts on employment and on school attendance and completion, suggesting that paid work experience tends to successfully motivate disadvantaged youth to participate in schooling or training. It is unclear whether these employment efforts had long-term effects. However, even modest reductions in dropout rates (and accompanying criminal activity) for disadvantaged youth might be cost-beneficial. 
Positive impacts have also been documented for mentoring and "youth development" programs like Big Brothers/Big Sisters (Herrera 1999) and, to some extent, for Quantum Opportunities. ${ }^{23}$ Although these are not workforce development or job training programs, they can be viewed as complements rather than substitutes for workforce-type efforts. Finally, the Youth Opportunities program earlier this decade was an attempt to saturate low-income neighborhoods (in 36 areas nationwide) with greater educational and employment opportunities for youth, and to build "systems" that better track these youth when they drop out of school, leave foster care and/or become incarcerated. This program was eliminated before any evaluation results became available, though early descriptive evidence seemed promising (USGAO 1996).

In sum, while much remains unknown about exactly what approaches are most successful for disadvantaged (especially out-of-school) youth, the successes noted above challenge the notion that "nothing works" for these youth.

\section{B. Other Approaches, Other Problems, and a Changing Labor Market}

The conclusion that job training programs for poor adults and youth are not costeffective, while not very accurate, has been reinforced by several widely held perceptions, including:

- Other approaches for improving the earnings of the disadvantaged are more cost-effective than training, and therefore are more worthy of scarce public dollars;

- Problems of the disadvantaged other than their lack of occupational skills and work experience are more serious; and

- A changing labor market is rendering job training less relevant than it might have been in previous generations.

I review each of these arguments below. 


\section{Are Other Approaches More Cost-Effective?}

For adults, the apparent success of welfare reform in raising employment and earnings among single mothers has been accompanied by a sense that "work first” approaches are more cost-effective than education and training. But wages for former welfare recipients remain quite low, with little evidence of rapid labor market advancement. If wage growth is hard to achieve, then one option is to continue raising their employment levels in low-wage jobs through low-cost approaches such as job search assistance, and then publicly supplement their low earnings through extensions of the Earned Income Tax Credit (EITC) (Scholz, Moffitt and Cowan, this volume), and by expanding child care subsidies other work supports.

But is it clear that these other efforts dominate job training in cost-effectiveness? My own calculations suggest that moderately effective training for adults and youth might be at least as socially efficient as the EITC. For instance, estimates suggest that every $\$ 1$ of expenditure on the EITC raises the earnings of single mothers by about $\$ .25$, and therefore raises their incomes by $\$ 1.25$ (without accounting for any welfare cost of taxation). ${ }^{24}$ This compares with the near doubling of earnings generated per net dollar spent on JTPA over a 5-year period that we noted above. Of course, most training programs are not necessarily this successful. And the two approaches are not mutually exclusive. But, given the high annual costs of the EITC relative to the very small sums now spent on training disadvantaged adults, I think that increased federal spending on WIA and/or Pell grants (in addition to some possible extensions of the EITC) is clearly warranted. ${ }^{25}$

\section{Are Other Problems More Serious?}

Recent efforts to improve skills and long-term earnings potential among the disadvantaged have focused not on adults and youth, but on young children (Jacob and Ludwig, 
this volume). Many "high school reform” efforts (Quint 2006) also focus primarily on cognitive skills and academic achievement and are designed to promote greater college attendance and completion, rather than training and work experience for high school students.

The current emphasis on younger children and academic skills reflect a growing awareness of:

- The large "achievement gap" between racial and income groups that develops very early in the lives of children (Jencks and Phillips, 1998; Fryer and Levitt, 2004);

- The ability of the "achievement gap" to account for large portions of differences in college attendance and completion and earnings differences (Johnson and Neal, 1998); and

- Evidence that relative and the real wages of high school graduates have stagnated while the college/high school earnings gap has widened dramatically since the 1970s (Blank et al., 2007).

Although the evidence on these three points is very solid, they do not necessarily imply an exclusive focus on early childhood preparation, test scores and college outcomes. A strong proponent of primarily investing in early childhood education (perhaps at the expense of later efforts) is Nobel laureate James Heckman (for instance, 2008). He documents that cognitive skill formation occurs most easily at very early ages, and that these early skills "beget" further cognitive skills over time. He also documents that noncognitive skills can be influenced at early (as well as somewhat later) ages, and these also affect labor market outcomes of high school graduates. The importance of early cognitive skill-building leads Heckman to conclude that the social returns to human capital enhancement decrease strongly with age, and that training programs beyond a certain age are not cost-effective. As a result, he advocates a major 
reorientation of resources away from training of youth and adults towards early childhood programs (along with some additional expenditures later in childhood, as these are viewed as complements with successful early childhood investment).

However, the empirical evidence on returns to education and training does not always fit the predicted declining pattern over the life-cycle (Karoly 2003). ${ }^{26}$ In particular, evidence of very strong returns on pre- $\mathrm{K}$ is relatively limited to a few small and intensive programs (like the Abecedarian and Perry Preschool programs) that have never been replicated or scaled up; while rigorous evaluation evidence of positive impacts from efforts that have gone to scale (like Head Start) is more limited and often reflects the state of the program as it was in the 1960s or 1970s rather than today (Jacob and Ludwig, this volume). Also, some newly popular statewide universal pre-K programs show highly varied short-term impacts on achievement (Wong et al. 2007) and quick fadeout of cognitive impacts (Hill 2007). And the strong returns per dollar spent in the estimated impacts of programs like the Career Academies, NSW and JTPA for adults suggest that some training programs for youth and adults are quite effective. ${ }^{27}$ Once again, I view the earlier investments in children and the later ones in youth and adults as complements, not substitutes, and support some expansion of both.

Similarly, I reject the notion that only test scores and cognitive achievement and ultimately college attendance merit public attention. Universal college attendance seems unachievable in the short term - especially when roughly a quarter of our youth are not finishing high school on time (Heckman et al. 2007). The modest goal of "some postsecondary for all" seems more appropriate, especially because most analysts include a range of potential community college training options and certifications. The returns to a year or more of community college and to various kinds of CTE in secondary school (like Career Academies and 
Tech Prep) are strong enough to justify some continued investment in these efforts (Lerman 2007).

\section{A Changing Labor Market}

The declining interest in training programs for the disadvantaged has been reinforced by two economic developments that have negatively affected their employment and earnings. First, some analysts expect that continuing globalization leading to greater offshoring of service activities and more immigration (Freeman 2007) might enable employers to meet their future labor needs more easily with foreign (or foreign-born) labor than by training native-born lesseducated workers. Second, some authors have documented growth in both high-skill and lowskill jobs relative to those in the middle (Autor et al. 2006). These developments imply that may be little reason to train less-educated workers for relatively unavailable middle-level jobs.

I caution against overstating these trends. Regarding globalization, immigrants are heavily concentrated at the bottom and top of the skills distribution (Borjas 2007); it is in middleskill jobs that the relative demand for labor may be least met by these workers. ${ }^{28}$ Also, many economic sectors that use middle-skill labor - such as health care, construction, retail trade and the like - will exhibit a strong "home bias," in which the work will remain in the U.S. where customers are located. Regarding labor market polarization, a recent study concludes that, while mildly shrinking, the middle of the labor market will continue to generate strong demands for hiring over the next decade and beyond (Holzer and Lerman 2007). This is especially true when one considers gross hiring, including "replacement" demand for retirees, rather than focusing exclusively on net employment shifts across these categories. Thus, I still see a need to train less-educated workers for jobs close to the middle of the skill spectrum.

\section{Summary}


On close examination, the arguments that investments in workforce development for the poor should diminish because other approaches are more cost-effective, other problems are more serious, and the labor market is changing are, like the arguments of weak cost-effectiveness, not terribly convincing. Perhaps the real reasons for why they have diminished so dramatically are political, rather than substantive. In a world of scarce fiscal resources, advocates for the poor might concentrate their limited political capital on direct cash assistance, like welfare or child care, rather than on the more indirect and longer-term benefits that might accrue from job training. And, as the resources have diminished over time, the interest in fighting for them has diminished as well. ${ }^{29}$ Whether this might change over time, if the possibility of a renewed commitment to public funding for workforce development becomes apparent, is unclear.

\section{Recent Labor Market Developments and Training Approaches}

In recent years, some newer approaches to workforce development for the poor have been developed that might be more effective than those reviewed above, and that generate more enthusiasm among state and local policymakers. These approaches tend to emphasize the importance of linking education and training more closely to jobs on the demand side of the labor market - especially for sectors and employers where well-paying jobs are still readily available for less-educated workers, and where these jobs will not be easily filled by employers

on their own. Targeting training for the disadvantaged to these sectors and jobs might thus serve a dual purpose of supporting economic development while also helping the poor, and thus improving labor market efficiency as well as equity. ${ }^{30}$

For instance, many state agencies and employers in key industries are very concerned about potential shortages of workers in the "middle-skill” jobs as Baby Boomers retire. These 
concerns are greatest in sectors with well-paying jobs where future labor demand will be strong (as in health care and elder care), and where the needs for specific skills (such as those of machinists, technicians and construction crafts) will not be easily met.

Many economists assume that these markets will equilibrate on their own, as relative wages adjust and as private investments in training (by both employers and workers) rise in response to high returns. But these forces will not necessarily eliminate all shortages, even in the long run, and certainly will not do so without costs for employers or local economies. Various market forces and failures might also limit private expenditures on training, especially by small and medium-sized employers and for disadvantaged workers. ${ }^{31}$

Thus, there are newer justifications for and some renewed interest in programs to help meet the needs of these workers as well as those of employers. Newer approaches to deal with other populations, like at-risk youth and the hard to employ, have been developed as well.

\section{New Approaches for Disadvantaged Adults}

Table 1 lists some promising new approaches for meeting employer demands by training disadvantaged adult workers, and some prominent programs around the country that apply these approaches, albeit at relatively small scales (Holzer and Martinson 2008). These approaches generally involve some combination of the following: 1) Education and training (sometimes but not always at community colleges) that give workers a postsecondary credential; 2) Direct ties to employers or industries that provide well-paying jobs in key sectors; and 3) A range of additional supports and services to help workers deal with problems that arise (such as child care and transportation), either during the training period or beyond.

In addition, labor market intermediaries often bring together the workers, employers, training providers and sources of supports needed to make this process work. The intermediaries 
might help overcome employer resistance to hiring workers (perhaps due partly to discrimination) by providing more information on positive worker skills and attributes, and by carefully screening the applicants whom they refer to these employers. If the basic skills of the workers are not sufficient for their participation in the needed occupational training, remedial "bridge programs" are used at the community colleges. Intermediaries provide not only job placements with employers in well-paying jobs, but also a range of post-employment services are sometimes included to deal with problems that frequently arise in new working contexts. The direct involvement of employers and the availability of jobs at the end of training help improve the "match" between the skills being acquired and the demand side of the labor market; in some cases, employers are even encouraged to change job structures and promotion ladders, so that more "good jobs" are created to match the new skills of workers. The direct ties to available jobs at wages above their current levels of earnings should also motivate the disadvantaged to undertake the training. On the other hand, workers often receive some certification that indicates development of both general and specific occupational skills, thereby providing opportunities for mobility across employers and occupations in the future.

The best-known approaches that combine some or all of these elements include "sectoral" training, "incumbent-worker” training, and the building of "career ladders" or "career pathways.” Sectoral training simply targets specific economic sectors at the local level where labor demand is strong and well-paying jobs are available for those without four-year college degrees. Incumbent worker training programs sometimes use state funds to subsidize employer-sponsored training and upward mobility for entry-level workers in the firms that currently employ them. Efforts to build career ladders into low-skill jobs, like nursing aide positions, might enable lowwage workers to progress either with their current employers or with other firms in the same 
industry. And career pathway programs have been built for particular industries in various states that reach into the high schools and community college populations, and that generate clear progressions to skilled jobs in these industries based on packages of education, training and work experience (Jenkins, 2006).

Because these are small scale programs that have not been rigorously evaluated, we do not know the extent to which they can be successfully scaled up, and whether or not they are cost-effective. But some sectoral programs - like the Extended Care Career Ladder Initiative (ECCLI) in Massachusetts or the Wisconsin Regional Training Partnership - have already achieved impressive scale. The "Career Pathways" and "Ready to Work" programs in Kentucky and Arkansas are statewide efforts to link community colleges to the working poor and to higherwage jobs and employers in those states. As for evaluation evidence, much of what we have today are descriptive outcomes for small programs, though some important evaluations are in progress and the results are pending (Conway et al. 2004).

Finally, some natural tensions might exist between "economic development” and antipoverty efforts that need to be addressed. Employers are often reluctant to become involved with antipoverty programs, which can tend to stigmatize the workers they are designed to help. The employers might well prefer to use public funding for others whom they might have hired and trained anyway. Targeting is needed to ensure that scarce public funds do not provide windfalls to such employers. At the same time, to maintain both employer interest and broader political support, some flexibility might be needed to provide funding to less-educated workers who are not necessarily poor.

\section{New Programs for Ex-Offenders and At-Risk Youth}


Among newer approaches to improve employment options for the "hard to employ", transitional jobs (TJ) have recently gained some popularity. Much like Supported Work, TJ generally provides adults who have little formal work history roughly 6-12 months of paid experience, either in a non-profit or for-profit setting (Holzer 2003). This is particularly important for the ex-offender population, given its enormous growth in recent years, and given the evidence of significant barriers to employment that they face (Travis, 2003). Thus, the Center for Employment Opportunity (CEO) in New York provides every ex-offender leaving Rikers' Island the opportunity for TJ. CEO has been evaluated with a random assignment design, and preliminary results suggest a sizable drop in recidivism for those entering TJ soon after release (Bloom et al. 2007). Other programs for ex-offenders (like the Safer Foundation in Chicago) provide training and job placement services without the guarantee of a TJ; these programs are considerably less expensive, though we do not know how cost-effective their services are. ${ }^{32}$ But whether any of these actually improve employment outcomes over the longer-term for exoffenders and the hard to employ more generally remain uncertain.

As for at-risk out-of school youth, a number of model programs are being investigated in a variety of settings. A variety of "dropout prevention" programs for youth in high school, both during school hours and afterwards, are being developed; some of these are programs within existing high schools while others involve broader efforts at "high school reform” (Quint, 2006). In addition, new "dropout recovery” models in alternative/charter schools now combine high school completion with the beginning of postsecondary education (Steinberg et al. 2003; Martin and Halperin 2006). 
In all of these cases, more rigorous evaluation is necessary before we can draw firm conclusions on what works. In the meantime, it is clearly premature to conclude that "nothing works”.

\section{Conclusion}

In a labor market which places a greater premium on skill development than ever before, we now spend dramatically fewer resources on the training of disadvantaged workers than we did in the 1970. I have reviewed trends in workforce training for the poor, what we know and don't know about its cost-effectiveness, and some new strategies.

In general, the evidence for adults indicates that modest training and work experience programs can generate modest impacts that are cost-effective even though they do not dramatically improve the lives of the poor. A small number of more intensive efforts, like the National Supported Work program for hard-to-serve women (and for somewhat older men), have been quite effective as well. A few other programs, like the Portland site in NEWWS and the original CET, were quite successful but have not yet been widely replicated.

Pell grants do expand access to (community) college for poor adults, who likely benefit when they can attend for at least a year and gain some certification or degree. A new generation of programs for the working poor - like "sectoral" models and "career pathways" - that are more closely tied to the demand side of the labor market and that provide workers with marketable credentials and a range of supportive services look promising; but these have mostly not been scaled up or rigorously evaluated.

Programs for youth who are still in school, like the Career Academies and Opening Doors, appear to be cost-effective. Others for out-of-school youth have not been as successful, 
though we do not yet have enough rigorous evidence on promising models such as YouthBuild, the Youth Service and Conservation Corps, or the National Guard Challenge Program. For exoffenders, some preliminary evidence on "transitional jobs" for ex-offenders suggests a reduction in recidivism, though less impact on subsequent earnings.

Overall, the conventional wisdom that "nothing works" with regard to training disadvantaged youth and adults, or even that investments in other kinds of education (like early childhood programs) or in work supports (like the EITC) are more cost-effective than workforce development, is not clearly supported by the evidence. I thus reject the view that the dramatic declines in federal investments in workforce development for the poor can be justified by a lack of cost-effectiveness or by other labor market developments.

On the other hand, there is reason to be skeptical that workforce development for disadvantaged adults and out-of-school youth will ever be sufficient on its own to dramatically improve their life chances. For the current stock of poor workers, many will likely never have access to additional training and might not benefit from it if they did. Perhaps workforce development is best seen as an important component of a broader strategy that also includes stronger income supplementation for the poor (like extensions of the EITC to childless adults and non-custodial fathers who do not now qualify for much); additional work supports (like child care and transportation) and benefits (like health insurance and parental leave); as well as a range of educational approaches that begin (but do not end) with high-quality early childhood and pre$\mathrm{K}$ programs. And, since so much remains unknown about exactly what is cost-effective in workforce development efforts for youth and adults, we need to generate a great deal more knowledge to guide policymakers in their choices. 
Thus, I would argue for the following policy priorities in the area of workforce development:

1. Greater funding should be available for Pell grants, since they now finance much of the community college training at the core of our workforce development system, and since funding has not kept up with growing needs. These should be supplemented by additional reforms, like those suggested by Susan Dynarski, to make Pell grants more effective and more accessible to low-income adults and youth.

2. Funding for the federal workforce system for adults should be expanded as well, to restore at least some of what has been cut so dramatically in recent years. WIA now pays for a range of employment services and training not funded by Pell grants. The other elements of workforce development that are funded through WIA - such as core and intensive services, funding of training for displaced workers, adult basic education (especially English instruction for immigrants) and administration of One-Stop offices, are worth preserving and expanding. But when WIA is reauthorized (or replaced) in 2009 or beyond, greater emphasis should be put on building state-level workforce development systems that target good jobs in growing sectors for the disadvantaged, with the kinds of demand-oriented training programs plus support services described above. Additional funding for programs that reduce recidivism among ex-offenders, and for other hard-toemploy workers, is warranted as well

3. Funding for effective programs for at-risk youth - such as high-quality career and technical education, efforts (like Opening Doors) to expand their access to higher education, and various categories of "youth development" and mentoring - should also 
be increased. States should receive greater federal support as they experiment with new dropout prevention and recovery efforts, and develop youth "systems” at the local level.

4. In all of the above categories, an aggressive program of rigorous evaluation should accompany all expansions of funding. The areas most in need of demonstration projects are where our knowledge remains most limited - such as what works to improve earnings for out-of-school youth and ex-offenders.

This list of priorities suggests that program expansion and rigorous evaluation should proceed simultaneously, and in ways where the latter can continuously inform the former over time. At least some of the funding increases should be implemented by "competitive" rather than "formula" grants to states or cities, where renewal of these grants over time should be conditional on strong observed performance and use of proven programs over time. Elsewhere (Holzer, 2007) I have outlined how the federal government could fund competitive grants for states to develop innovative programs. The federal government would provide states with substantial oversight and technical assistance, and would also provide bonuses for performance. ${ }^{33}$ Rigorous evaluation would be required. And renewal of grants to states in subsequent years would be conditional on the incorporation of lessons learned through evaluation. Such a system could be designed as a complement to the current WIA system, or as a major part of a new reform effort.

Whatever path is taken, we need to expand funding for a range of workforce development efforts for disadvantaged youth and adults. At the same time, some consolidation of the dozens of programs in the federal budget that now fund employment and training, and some reforms aimed at improving system performance, is also warranted. 


\section{References}

American Council on Education, 2004. "Fact Sheet on Higher Education.” Center for Policy Analysis.

Andersson, Fredrik; Harry J. Holzer and Julia Lane. 2005. Moving Up or Moving On: Who Advances in the Low-Wage Labor Market? New York: Russell Sage Foundation.

Autor, David; Lawrence Katz and Melissa Kearney. 2006. “The Polarization of the U.S. Labor Market.” National Bureau of Economic Research (NBER) Working Paper.

Bloom, Howard; Larry Orr, Stephen Bell, George Cave, Fred Doolittle, Winston Lin, and Johannes Bos. 1997. “The Benefits and Costs of JTPA Title II-A Programs.” Journal of Human Resources, 32:3, 549-76.

Bloom, Dan; Cindy Redcross, Janine Zweig, and Gilda Azurdia. 2007. “Transitional Jobs for Ex-Prisoners.” New York: MDRC.

Borjas, George. 2007. “Immigration Policy and Human Capital.” In H. Holzer and D. Nightingale eds. Reshaping the American Workforce in a Changing Economy. Washington DC: Urban Institute Press.

Bos, Johannes; Susan Scrivener, Jason Snipes, and Gayle Hamilton. 2001. "Improving Basic Skills: The Effects of Adult Education in Welfare-to-Work Programs.” New York: MDRC.

Carasson, Adam; Harry Holzer, Elaine Mag, and Eugene Steuerle. 2008. "The Next Age for Social Policy: Encouraging Work and Family Formation among Low-Income Men.” Wasington DC: The Urban Institute.

Cohen, Mark and Alex Piquero. 2008. "Costs and Benefits of a Targeted Intervention Program for Youth Offenders:The Youth Build USA Ex-Offender Project.” Unpublished manuscript, Vanderbilt University.

Conway, Maureen; Llinda Dworak-Munoz and Amy Blair. 2004. "Sectoral Workforce Development: Research Review and Future Directions.” Washington DC: Workforce Strategies Institute, The Aspen Institute.

Dynarski, Susan and Judith Scott-Clayton. 2007. "College Grants on a Postcard: A Proposal for Simple and Predictable Federal Student Aid. Washington DC: The Brookings Institution, The Hamilton Project.

Ellwood, David and Elisabeth Welty. 2000. "Public Service Employment and Mandatory Work: A Policy Whose Time Has Come and Gone and Come Again?” In D. Card and R. Blank eds. Finding Jobs: Work and Welfare Reform. New York: Russell Sage Foundation. 
Frank, Abbey and Elisa Minoff. 2005. "Declining Shares of Adults Receiving Training under WIA Are Low-Income or Disadvantaged.” Washington DC: Center on Law and Social Policy.

Freeman, Richard. 2007. "Is a Great Labor Shortage Coming? Replacement Demand in a Global Economy.” In Holzer and Nightingale eds., op. cit.

Hamilton, Gayle. 2008. "Promoting Stable Employment and Wage Progression: Findings from the Employment Retention and Advancement (ERA) Project.” New York: MDRC.

Hamilton, Gayle; Stephen Freedman, Lisa Gennetian, Charles Michalopoulos, Johanna Walter, Diana Adams-Ciardullo, and Anna Gassman-Pines. 2001. "How Effective are Different Welfare-to-Work Approaches? Adult and Child Impacts in Eleven Programs. New York: MDRC.

Heckman, James. 2008. “Schools, Skills, and Synapses.” NBER Working Paper.

Heckman, James and Paul LaFontaine. "The American High School Graduation Rate: Trends and Levels” 2007. Unpublished manuscript, University of Chicago.

Heckman, James; Robert Lalonde and Jeffrey Smith. 1999. "The Economics and Econometrics of Active Labor Market Programs.” In O. Ashenfelter and D. Card eds. Handbook of Labor Economics, Vol. 3A. Amsterdam: North Holland.

Herrera, Carla. 1999. School-based Mentoring: A First Look into Its Potential. Philadelphia: Private/Public Ventures.

Hill, Carolyn J. 2007. "The Longer-Term Effects of a Universal Pre-Kindergarten Program." Working paper, Georgetown University.

Holzer, Harry J. 2007. "Better Workers for Better Jobs: Improving Worker Advancement in the Low-Wage Labor Market.” The Hamilton Project, The Brookings Institution, Washington DC.

Holzer, Harry J. 2003. "Can Work Experience Programs Work for Welfare Recipients?” Welfare Reform and Beyond, Brief No. 24, The Brookings Institution, Washington DC.

Holzer, Harry J. and Robert Lerman. 2007. “America’s Forgotten Middle-Skill Jobs: Education and Training Requirements for the Next Decade and Beyond.” Washington DC: The Workforce Alliance.

Holzer, Harry J. and Karin Martinson. 2008. "Helping Poor Working Parents Get Ahead: Federal Funds for New State Strategies and Systems." Washington DC: The Urban Institute.

Hotz, V. Joseph; Guido Imbens and Jacob Klerman. 2000. "The long-term gains from GAIN: A. re-analysis of the impacts of the California GAIN program.” NBER Working Paper. 
Jacob, Brian and Jens Ludwig. 2008. "Improving Educational Outcomes for Poor Children.” Paper in this Volume.

Jastrzab, Joann; John Blomquist, Julie Masker and Larry Orr. 1997. "Youth Corps: Promising Strategies for Young People and their Communities.” Cambridge MA: Abt Associates.

Jenkins, Davis. 2006. “Career Pathways: Aligning Public Resources to Support Individual and Regional Economic Advancement in the Knowledge Economy.” New York: Workforce Strategies Center.

Johnson, William and Derek Neal. 1998. "Basic Skills and the Black-White Earnings Gap.” In C. Jencks and M. Phillips eds. The Black-White Test Score Gap. Washington DC: The Brookings Institution.

Karoly, Lynn. 2003. "Caring for our Children and Youth: An Analysis of Alternative Investment Strategies.” Los Angeles CA: The Rand Corporation.

Kemple, James. 2008. “Career Academies: Long-Term Impacts on Labor Market Outcomes, Educational Attainment and Transitions to Adulthood.” New York: MDRC.

Lalonde, Robert. 2003. "Employment and Training Programs.” In R. Moffitt ed. MeansTested Transfer Programs in the U.S. Chicago: University of Chicago Press.

Lerman, Robert. 2007. “Career-Focused Education and Training for Youth.” In H. Holzer and D. Nightingale eds., op. cit.

Lerman , Robert; Signe-Mary McKernan and “Stephanie Riegg. 2004.”Employer Provided Training and Public Policy.” In O’Learn et al. eds.

Martin, Nancy and Samuel Halperin. 2006. "Whatever It Takes: How Twelve Communities Are Reconnecting Out-of-School Youth.” Washington DC: American Youth Policy Forum.

Melendez, Edwin. 1996. Working on Jobs: The Center for Employment Training. Boston MA: Mauricio Gaston Institute.

Miller, Cynthia; Johannes Bos, Kristin Porter, Fannie Tseng and Yasuyo Abe. 2005. “The Challenge of Repeating Success in a Changing World: Final Report on the Center for Employment Training Replication Sites.” New York: MDRC.

Mueser, Peter; Kevin Troske and Alexey Gorislavsky. 2005. "Using State Administrative Data to Measure Program Performance.” Working Paper, University of Missouri, Columbia, MO. 
O’Leary, Christopher; Robert Straits, and Stephen Wandner. 2004. ”U.S. Job Training: Types, Participants and History.” In O’Leary et al. eds. Job Training Policy in the United States. Kalamazoo MI: W.E. Upjohn Institute for Employment Research.

Quint, Janet. 2006. Meeting Five Critical Challenges of High School Reform. New York: MDRC.

Reimers, Cordelia. 1983. "Labor Market Discrimination against Black and Hispanic Men.” Review of Economics and Statistics. 65:4, 570-79.

Riccio, James. 2007. "Subsidized Housing and Employment: Building Evidnece of What Works to Improve Self-Sufficiency.” New York: MDRC.

Riccio, James. Daniel Friedlander, Stephen Freedman. 1994. "GAIN: Benefits, Costs, and Three-Year Impacts of a Welfare-to-Work Program.” New York: MDRC.

Richburg-Hayes, Lashawn. 2008. "Helping Low-Wage Workers Persist in Educational Programs. New York: MDRC.

Schirm, Allen; Nuria Rodriguez-Planas, Myles Maxfield, and Christina Tuttle. 2003. "The Quantum Opportunities Demonstration: Short-Term Impacts.” Princeton NJ: Mathematica Policy Research.

Schochet, Peter; Sheena McConnell and John Burghardt. 2003. "National Job Corps Study: Findings Using Administrative Earnings Records Data.” Princeton NJ: Mathematica Policy Research,.

Scholz, J. Karl; Robert Moffitt and Cowan. Paper in this volume.

Simonetta, Jonathan. 2004. “Appendix A: Job Training Data.” In Christopher O’Leary, Robert Straits, and Stephen Wandner.” Job Ttraining Policy in the United States. Kalamazoo MI: W.E. Upjohn Institute for Employment Research.

Spence, Robin and Brendan Kiel. 2003. "Skilling the American Workforce 'On the Cheap’: Ongoing Shortfalls in Federal Funding for Workforce Development. Washington DC: The Workforce Alliance.

Steinberg, Adria; Cheryl Almedia, Lili Allen and Sue Goldberger. 2003. "Four Building Blocks for a System of Educational Opportunity: Developing Pathways to and Through College for Urban Youth.” Boston MA: Jobs for the Future.

Travis, Jeremy. But They All Come Back: Facing the Challenge of Prisoner Reentry. Washington DC: The Urban Institute.

Turner, Sarah. 2007. "Higher Education Policies Generating the $21^{\text {st }}$ Century Workforce.” In H. Holzer and D. Nightingale eds., op. cit. 
Uggen, Christopher. 2000. "Work as a Turning Point in the Life Course of Criminals: A Duration Model of Age, Employment and Recidivism.” American Journal of Sociology. 65:4, 529-46.

United States General Accounting Office. 1996. Job Training Partnership Act: LongTerm Earnings and Employment Outcomes. Washington DC: United States Government Printing Office.

United States General Accounting Office. 2003. Multiple Employment and Training Programs: Funding and Performance Measures for Major Programs. Washington DC: United States Government Printing Office.

United States General Accounting Office. 2006. Youth Opportunity Grants: Lessons Can Be Learned, But Labor Needs to Make Data Available. Washington DC: United States Government Printing Office.

Wong, Vivian; Thomas Cook, Steven Barnett and Kwanghee Jung. 2008. “An Effectiveness-Based Evaluation of Five State Pre-Kindergarten Programs.” Journal of Policy Analysis and Management, 27:1, 122-54. 


\section{Table 1}

\section{New Training Approaches: Promising State and Local Programs}

\section{Sectoral Training Programs}

- Cooperative Home Care Associates (CHCA) - Developed by the Paraprofessional Health Care Institute in the Bronx, CHCA is a worker-owned home health care cooperative that trains and employs home health care aides. Founded on the belief that higher quality jobs will lead to higher quality care, CHCA aims to restructure the long-term care industry by serving as a model employer that offers higher wages and benefits, supportive services, full-time work, opportunities for career growth, and reduced turnover. The program provides classroom training, on-the-job training, and peer mentorship. As employees of CHCA, are guaranteed a paid wage for a minimum of 30 hours per week, receive free health insurance, and earn dividends. Internal career ladders offer employees the opportunity to move into higher-paying administrative positions. Over 900 workers are members of the cooperative, and over 200 per year join annually and receive training.

- AFSCME 1199c Training and Upgrading Fund - Funded through 1.5 percent of gross payroll by participating hospitals, nursing homes and other providers in Philadelphia, this program provides training and career ladders for certified nursing assistants (CNAs) and licensed practical nurses (LPNs). Each student is placed with a case manager to provide ongoing career and personal counseling. In 2005, the program provided training to over 4,000 individuals.

- Wisconsin Regional Training Partnership (WRTP) - WRTP is a nonprofit association of businesses and unions that has served employers, employees, job seekers, and unions in the Milwaukee area since 1996. WRTP works in several industries including manufacturing, health care, construction, and hospitality. Firms that join WRTP agree to develop education and training programs on-site or at community colleges and provide a payroll contribution. In return, they receive technical assistance to strengthen technology and workplace practices, improve the skills of incumbent workers, and recruit and train new workers. Nearly 100 employers with about 60,000 workers participate.

Career Ladder Programs

- Kentucky Career Pathways - Operating at all sixteen community and technical colleges in the state, this initiative generates partnerships with businesses and has developed "pathways" in health care, manufacturing, construction and transportation. It mostly targets incumbent workers for training and upgrading with their companies. Participating institutions are encouraged to offer curriculums in modularized formats, at alternative times (such as evening and weekends), and at alternative sites, such as at the workplace. Colleges are also encouraged to integrate intensive student support systems including improved advising, mentoring and career counseling strategies. Currently over 1100 workers are participating.

- Arkansas Career Pathways - Instituted at 11 community colleges (out of 22) around the state, the program has created career pathways in a variety of sectors and has served about 2000 workers in a short time period. The program features training programs that are clearly and closely linked to real local job opportunities upon graduation; “bridge,” classes providing basic skills and workplace competencies that bring students to skill levels required for college entry; "fast track" two semester developmental education programs that provide contextualized instruction to reach skill level required for advanced college courses; and 
intensive support services offered by a case manager that provides academic advising and access to other supports, including child care and transportation.

- Massachusetts Extended Care Career Ladder Initiative (ECCLI) - ECCLI aims to improve the quality of nursing home care through instituting career ladders and promoting skill development and other supportive practices among nursing home staff. The program provides grants to nursing homes and home health agencies who may partner with other long-term care facilities, community colleges, WIBs, and others to create new career ladders for direct care staff and to address staff training, work environment, and quality of care issues. Partnerships involve 15 community colleges around the state and over 150 nursing homes (about $20 \%$ of the total). Over 7500 workers have participated to date. Most are CNAs seeking to upgrade skills and perhaps become LPNs.

Incumbent Worker Programs

- New Jersey Workforce Development Program - Operated by the New Jersey Department of Labor and all 19 community colleges in the state, the program funds incumbent worker training through grants to employers. It also includes the Supplemental Workforce Fund for Basic Skills, to finance basic education related to work. In Fiscal Year 2006 the latter program alone funded over 14,000 individuals. The program pays for the cost of the training, while employers pay workers wages while they attend classes (usually at the worksite). The programs are financed by Unemployment Insurance (UI) taxes on both employers and workers.

- Pennsylvania Incumbent Worker Training Fund - The Incumbent Worker Training Fund is a large-scale statewide initiative to enhance the skills and earnings of incumbent workers in key targeted industries. The programs provides grants to regional partnerships throughout the state between multiple employers, workforce development systems and educational institutions and has trained over 4,000 individuals. Begun in 2005, the program is complemented by the Workforce and Economic Development Network of Pennsylvania that provides grants to 28 community colleges to deliver basic skills to workers at their employer.

Source: Holzer and Martinson (2008). 
Figure 1

Worker Training in Primary DOL Programs, 1963-2003

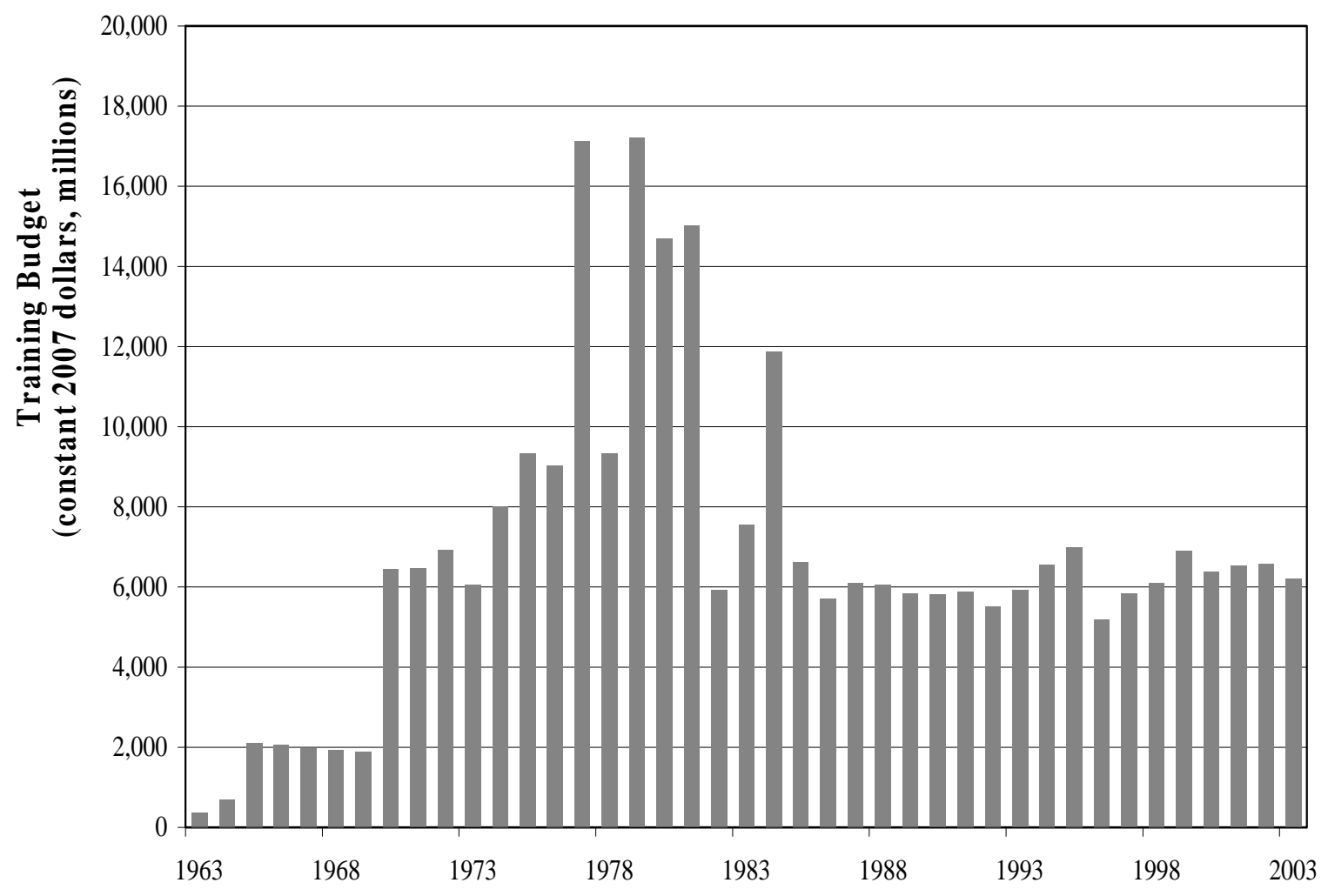




\section{NOTES}

${ }^{1}$ MDTA was preceded by the Area Redevelopment Act in 1961, a smaller effort that included at least some of the ideas contained in the later pieces of legislation.

${ }^{2}$ The view that public service jobs were wasteful and poorly managed was fed by a series of press reports in the late 1970s that highlighted workers expending little effort under little oversight on projects that produced little output (O’Leary et al, 2004). Ellwood and Welty (2000) discuss the conditions under which public jobs do or do not mostly substitute for production and employment in the private sector.

${ }^{3}$ Other titles of WIA fund adult literacy programs and the labor exchange functions of the Employment Service. Other employment and training programs funded by DOL, such as those for workers displaced by trade (as part of the Trade Adjustment Assistance program), the Community Service Employment program for senior citizens, and the High Growth Job Training Initiative, are not included within WIA and do not target the disadvantaged.

${ }^{4}$ See O'Leary et al. (2004) for a listing that includes remedial training in the classroom (and focusing both on basic academic and "soft skills," such as language and communication; "customized" training for particular employers and sectors; and "postemployment training" in classrooms or directly on the job. "Work experience" programs that try to generate basic job-readiness for the "hard to employ" can also fit into this definition.

${ }^{5}$ According to Simonetta (2004), most of the 200-300,000 disadvantaged adults receiving JTPA services each year in the 1990s received some training. Only about 100,000 now receive training in any year, and they constitute just a fifth of all adult workers (excluding the dislocated) receiving WIA services. The fractions of dislocated workers receiving training have also fallen from about 60 percent in the late 1990s to about 30 percent in 2005.

${ }^{6}$ This list omits programs that provide tax credits for the employment of specified groups (like the Work Opportunity Tax Credit) or funds for labor exchange services only, as these do not qualify as "training." It also omits programs that primarily fund education, as opposed to labor market training, as I note below.

${ }^{7}$ Spence and Kiel estimate that less than 10 percent of CSBG funds are spent on employment programs, though these expenditures under SSBG have fluctuated over time.

${ }^{8}$ Stafford loans and the Federal Work-Study program, are for those with "financial need" but are not strictly limited to the poor and do not provide scholarships without repayment or work obligations.

${ }^{9}$ Between FY 1979 and 2002, the share of total average costs of attending a public 4-year college covered by the maximum Pell grant fell from 77 to $41 \%$ (American Council on Education, 2004). The maximum Pell grant will rise through 2012, and the share of costs it covers will likely rise as well, but not to anywhere close to the 1970s level.

${ }^{10}$ Courses that are not part of a degree or certificate program are not covered by Pell grants.

${ }^{11}$ The returns to training for those who actually enrolled in the program represent an estimate of the "treatment effect on the treated" (TOT) as opposed to the smaller "intent to treat" (ITT) effect for all those assigned (Heckman et al. 1999). Under JTPA, the share of workers getting training were only 50-60 percent for the treatment group, as opposed to 20-30 percent for the control group.

${ }^{12}$ Heckman et al. (1999) report wage gains of 2-3\% for NJS adults, though these were not significant. Larger and more significant wage increases have been observed in other programs, like the Career Academies discussed below.

${ }^{13}$ Estimates of direct program expenditures do not include the opportunity cost of lost work time for those in training. But these costs are netted out of cumulative earnings gains, which are usually measured from the time at which the assignment to experimental v. control group is made.

${ }^{14}$ The "welfare cost" of taxation refers to the economic value of the inefficiencies associated with taxation, above and beyond the actual dollar value of the tax. Assuming welfare costs of .50 per dollar of tax, the estimated net social benefits by Heckman et al. are still over \$1000 (or over \$1500 in 2007 dollars) for both adult men and women. Assuming the high rate of $\$ 1.00$ of welfare cost per dollar of tax still generates net social benefits of over $\$ 1000$ for men and over about $\$ 600-800$ for women (or \$1500 and \$900-12000 in 2007 dollars), depending on assumptions about the discount rate.

${ }^{15}$ According to Lalonde, these programs generated earnings gains of $\$ 630$ and $\$ 1390$ respectively during the first two years after random assignment, while program costs were under $\$ 1250$ (all in 2007 dollars).

${ }^{16}$ Hamilton reports annual earnings impacts averaging over $\$ 1000$ per year in years 2 through 5 (or over \$1200 in 2007 dollars), with little fadeout by the final year, where average costs per participant were under $\$ 3000$ (or $\$ 3600$ in 2007 dollars).

${ }^{17}$ For instance, the Jobs Plus demonstration combined employment services with rent subsidies in public housing projects and generated significant earnings impacts for participants (Riccio 2007). The Illinois site in the Employment Retention and Advancement (ERA) project also emphasized assistance in placing low earners into better jobs, which generated positive earnings impacts as well (Hamilton et al. 2008). 
${ }^{18}$ Lalonde reports earnings impacts of over $\$ 740$ annually in the first two years and over $\$ 1240$ annually in the next three, with costs per participant about $\$ 10,660$ (2007 dollars).

${ }^{19}$ Lalonde notes earnings impacts of about $\$ 1825$ per year during the first two years at a program cost of just over $\$ 6000$ (2007 dollars).

${ }^{20}$ Reimers (1983) show that limited English language facility contributes importantly to wage differences between native-born whites and immigrant Hispanics, but we have little evidence to date on the effectiveness of programs to remediate language proficiency for adults.

${ }^{21}$ Job Start, a version of Job Corps that didn’t include a residential component, had few significant impacts, even in the short run (Lalonde 2003).

${ }^{22}$ Over the full follow-up period, monthly earnings impacts were 17 percent for young men, and even higher for those considered at high risk. Impacts on hourly wages accounted for nearly half of the monthly earnings impact.

${ }^{23}$ Quantum Opportunities provides four-year mentors to students, beginning in the ninth grade, and other financial incentives and educational supports. The most recent evaluation, (Schirm et al. 2003) showed positive short-term effects but smaller long-term effects on dropout rates and other outcomes.

${ }^{24}$ Details of these calculations are available from the author.

${ }^{25}$ Elsewhere (Carasso et al 2008) I have argued for extending the EITC to childless adults, especially adult men who are non-custodial parents of children and who pay child support.

${ }^{26}$ Karoly's findings were at least partly based on strong estimated impacts of the Job Corps and Quantum Opportunities, which faded out or failed to be fully replicated in subsequent evaluations. Her summary still includes many interventions for youth and adults that appear fairly cost-effective.

${ }^{27}$ Heckman himself notes the quite positive impacts of JTPA, at least under some assumptions, and of NSW for disadvantaged adult women in his 1999 paper with Lalonde and Smith. In keeping with his view that positive noncognitive impacts on adolescents and teens are achievable, he praises youth development and mentoring programs for in-school youth in some of his writings as well.

28 "Middle-skill” jobs might be defined as those requiring something more than a high school diploma, in terms of education or training or work experience, but less than a bachelor's degree.

${ }^{29}$ Indeed, the willingness of big-city mayors to fight for these funds has dropped off considerably since the late 1970s, when CETA expenditures on public service jobs and other kinds of training were so much more substantial. ${ }^{30}$ Andersson et al. (2005) stress the importance of improving the access of the poor to well-paying jobs in highwage firms and sectors to improve their advancement prospects in the labor market.

${ }^{31}$ For instance, workers might underinvest in education and training due to imperfect information or constraints that prevent them from borrowing in credit markets. Employers might also underinvest in training their workers for the same reasons. Even in well-functioning markets, employers will not want to invest in training for "general" skills, since employees might leave before they can reap the returns on these investments; while wage rigidities in some sectors might prevent employees from accepting the lower wages needed to pay for their training at these firms. See Lerman et al. (2004). In sectors like health care and elder care, third party reimbursement rules (from insurers) might restrict the wage and salary adjustments that are necessary to attract and train enough workers to "equilibrate" supply and demand in the market.

${ }^{32}$ These programs tend to focus on the labor market, but provide little treatment for substance abuse or mental health issues (like Post Traumatic Stress Disorder), and therefore are already targeted towards the relatively more job-ready portion of the offender population.

${ }^{33}$ Since performance measures for program participants can be manipulated through who is allowed to enter or exit the program, these should be supplemented or even replaced by state-wide measures where improvement is expected in employment outcomes. This would also encourage states to build greater scale into their efforts. 